\title{
Bio-Sand Filter (BSF): A Simple Water Treatment Device for Safe Drinking Water Supply and to Promote Health in Hazard Prone Hard-to-Reach Coastal Areas of Bangladesh
}

\author{
A. H. M. Enamul Kabir, Tapos Kumar Chakraborty, Gopal Chandra Ghosh ${ }^{*}$ \\ Department of Environmental Science and Technology, Jessore University of Science and Technology, Jessore, Bangladesh
}

Email address:

shimul.enamu1778@gmail.com (A. H. M. E. Kabir), taposchakraborty@rocketmail.com (T. K. Chakraborty), gopales8@hotmail.com (G. C. Ghosh)

${ }^{*}$ Corresponding author

To cite this article:

A. H. M. Enamul Kabir, Tapos Kumar Chakraborty, Gopal Chandra Ghosh. Bio-Sand Filter (BSF): A Simple Water Treatment Device for Safe Drinking Water Supply and to Promote Health in Hazard Prone Hard-to-Reach Coastal Areas of Bangladesh. American Journal of Environmental Protection. Vol. 5, No. 5, 2016, pp. 109-114. doi: 10.11648/j.ajep.20160505.11

Received: July 21, 2016; Accepted: August 1, 2016; Published: August 15, 2016

\begin{abstract}
This study investigated a locally assembled 'Bio-Sand Filter (BSF)' water treatment device for low cost household level drinking water supply in hazard-prone hard-to-reach coastal areas of Bangladesh to promote health. The device was made using locally available materials (plastic bucket, sand and gravel). Overall study results revealed a greater portion of turbidity reduction $(>99 \%)$ in the filtrate. The filter was found to reduce 1.5-log of total coliform and 1.6-log of fecal coliform, though it is not capable of consistently meeting the WHO guideline to be less than 1CFU per $100 \mathrm{ml}$ for both fecal and total coliform. The chlorination results showed that $2.4 \mathrm{mg} / \mathrm{L}$ chlorine doses were effective in post treatment of the filtrate and meet the recommended WHO guidelines to have free chlorine at least $0.5 \mathrm{mg} / \mathrm{L}$ to $1.0 \mathrm{mg} / \mathrm{L}$ in the stored water after $24 \mathrm{hr}$ to protect water from recontamination. The results led to the conclusion that one device could provide enough drinking water ( 24 to $50 \mathrm{~L}$ ) to satisfy the needs of a large representative household. The filters reduce the risks of contamination between the water source and at the point of consumption through improving water quality that can be translated into improved health outcomes.
\end{abstract}

Keywords: Bio-Sand Filter, Low-Cost Water Supply, Public Health, Hard-to-Reach Area

\section{Introduction}

Access to a regular, safe water supply is defined as a basic human right by the UN Committee on Economic, Social and Cultural Rights (CESCR) under General Comment No.15: The Right to Water (Arts. 11 and 12 of the Covenant) published in 2003 [1]. Safe water is critical to protect and maintain health [2] and attaining wider human development goals [3]. In Bangladesh, there is an abundance of water, but scarcity of safe drinking water is the reality at present. Nearly one fourth of the population has no access to safe drinking water [4]. Despite finding an increasing trend in accessing to improved water sources, the Joint Monitoring Programme (JMP) report 2015 shows there is still $13 \%$ of the total population in Bangladesh are under the unimproved sources of drinking water mainly due to salinity and arsenic contamination [5].
The southwestern coastal region of Bangladesh has been identified as the most hazard-prone hard-to-reach areas in Bangladesh. Despite being a tremendous development potential area, the people of coastal areas in Bangladesh, usually lead their life fighting against cyclone, tidal surge, flood, salinity, drinking water scarcity and so on. Salinization of drinking water sources is becoming a major problem and climate change has further worsened the situation. The presence of high level of salt in drinking water sources in coastal Bangladesh is a cause of public health concern and a challenge for the Government of Bangladesh, donor communities, and non-governmental organizations [6-8]. About 15 million people already are forced to drink saline water and in total 30 million people are unable to collect potable drinking water due to a lack of available safe water sources in the coastal areas of Bangladesh [9]. Inadequate access to safe water contributes 
to a high incidence of waterborne diseases $[10,11]$. Higher rates of (pre)eclampsia and gestational hypertension in pregnant women in coastal Bangladesh, compared with non-coastal pregnant women, were hypothesized to be caused by saline contamination of drinking water [12]. Recent research has suggested that in addition to interventions in water, sanitation and hygiene, improved water quality can reduce diarrheal disease morbidity by more than $30 \%[13,14]$. And in an effort to address the above problem, many aid agencies have turned to household water treatment methods and water filtration [15-17]. In regions where safe water supply is not available or reliable, point-of-use (POU) treatment systems such as household water treatment and safe storage technologies are an effective alternative [18].

The aim of the study is to design and test a low-cost household level water treatment device, Bio-Sand Filter (BSF), for safe drinking water supply in the hazard-prone hard-to-reach coastal areas of Bangladesh where peoples are taking untreated pond water or saline groundwater for drinking purpose.

\section{Materials and Methods}

\subsection{Materials}

Plastic container, sand from crushed rock, gravel, filter fittings, pond water and Commercial "Bleaching powder" as free chlorine source to analyze free chlorine residual.

\subsection{Filter Construction, Installation and Operation}

The BSF was made by using locally available plastic container, sand and gravel (Figure 1). The container was first cleaned with tap water, and were filled with $3 \mathrm{~cm}$ deep under drain gravel (12 $\mathrm{mm}$ diameter), $3 \mathrm{~cm}$ of separating gravel (6mm diameter) layer and $30 \mathrm{~cm}$ sand (screened through $<1$ $\mathrm{mm}$ mesh) layer in succession. Water was present in the containers before loading the filter media to avoid any occurrence of air spaces and short circuiting. The outlet pipe was provided in such a manner that a standing water layer depth of $3 \mathrm{~cm}$ is maintained over the filter media. A plastic diffuser plate was placed on the lip of the filter to avoid disturbance to the top layer of sand during daily charging of the filter with source water. The filters had a pore volume of $12 \mathrm{~L}$. The filter was charged twice $(12 \mathrm{~L}+12 \mathrm{~L})$ a day with pond water under an experimental flow rate of $50 \mathrm{~mL} / \mathrm{min}$ for the operational cycle. In the case of $12 \mathrm{~L}$ charge, since the reservoir of the filters could hold only about $12 \mathrm{~L}$, the second $12 \mathrm{~L}$ was poured approximately 10 hour later after the first 12 $\mathrm{L}$ water was poured. The test was conducted at room temperature, and water temperature varied in the range of 26 $34^{\circ} \mathrm{C}$ during the testing period.

\subsection{Water}

Pond water was used as feed water for the filter, and the freshly filtered water was collected from the BSF outlet pipe. Time between collection and analysis was minimized and analysis was done immediately after collection of the last sample and it was no longer than three to four hours.

\subsection{Chlorination of the Filtrate}

Chlorine dose was applied to inactivate the residual microbial concentration and secure the stored water from recontamination. Commercial grade bleaching powder was used as free chlorine source. It typically contains $25-30 \%$ available chlorine [19]. Chlorine dose was estimated as $2.4 \mathrm{mg} / \mathrm{L}$ and $4.8 \mathrm{mg} / \mathrm{L}$ in real time experiment for the both source water and the filtrate along with control tests using deionized water.

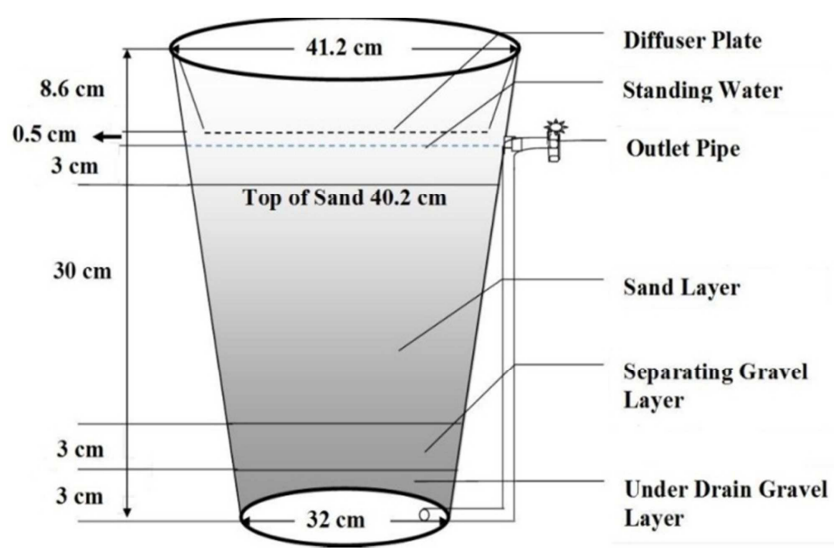

Figure 1. Schematic diagram of the BSF used in the study. All dimensions are in $\mathrm{cm}$.

\subsection{Analysis}

The source water and the BSF filtrate were monitored for turbidity, fecal coliform, total coliform and additionally free chlorine residual concentration was measured. The BSF filtrate tests were started after three weeks of filtration unit installation as per recommendation of CAWST to grow up the biolayer [20]. The BSF filtrates were collected for testing after approximately 3-5 L of filtrate had been discharged, so that diurnal results were comparable. Turbidity was measured using a HACH Model DR 2100 spectrophotometer in Nephelometric Turbidity Units (NTU) [21]. Both fecal and total coliform were measured using the membrane filtration procedure following standard method [22]. Free Chlorine was measured by HACH DR 2700 using method 8021 [23]. Chlorine demand was calculated from the difference between initial and final concentration of free chlorine in the samples. All data analysis was performed on 'Microsoft Excel 2013'.

\section{Results and Discussions}

\subsection{Source Water Characteristics}

The source water characteristics (Table 1) that the water was highly contaminated with fecal and total coliforms. There the total coliform concentrations ranged from 540-660 CFU per $100 \mathrm{ml}$ and fecal coliform concentrations were in the range of $310-410$ CFU per $100 \mathrm{ml}$. The pond may be affected by the indiscriminate use and unhygienic sanitary practices in that 
area. Surface waters in rivers and unprotected ponds often show fecal coliform counts between 500 and 3000 per $100 \mathrm{ml}$ in the coastal areas of Bangladesh [24]. Turbidity, on average, was very high ranging from 533-585 NTU. Average pH, EC and TDS data of raw water were suitable for its use as drinking water source. Ammonia and nitrate concentrations were found in lesser concentration in which the mean were $0.69 \mathrm{mg} / \mathrm{L}$ and $0.92 \mathrm{mg} / \mathrm{L}$, respectively. Besides, the application of organic and inorganic fertilizers for fish cultivation in ponds aggravates the deterioration of water quality [24]. This can be thought that the source was not intervened by intensive agriculture practices or fish cultivation in the source pond area. However, phosphate concentration ranged from 4.4 - $4.7 \mathrm{mg} / \mathrm{L}$, was found higher and it could be thought that the pond was used and intervened by local people through use of detergents for washing purposes.

Table 1. Source Water Characteristics.

\begin{tabular}{ll}
\hline Parameter & Source Water (Mean \pm SD) \\
\hline Turbidity (NTU) & $560 \pm 21.24$ \\
$\mathrm{pH}$ & $8.07 \pm 0.15$ \\
$\mathrm{EC}(\mathrm{mS} / \mathrm{cm})$ & $432 \pm 8$ \\
$\mathrm{TDS}(\mathrm{mg} / \mathrm{L})$ & $693 \pm 13$ \\
$\mathrm{NH}_{4}-\mathrm{N}(\mathrm{mg} / \mathrm{L})$ & $0.69 \pm 0.02$ \\
$\mathrm{NO}_{3}-\mathrm{N}(\mathrm{mg} / \mathrm{L})$ & $0.92 \pm 0.04$ \\
$\mathrm{PO}_{4}(\mathrm{mg} / \mathrm{L})$ & $4.46 \pm 0.13$ \\
$\mathrm{Fecal} \mathrm{Coliform}(\mathrm{CFU} / 100 \mathrm{~mL})$ & $348 \pm 26$ \\
Total coliforms $(\mathrm{CFU} / 100 \mathrm{~mL})$ & $588 \pm 46$ \\
\hline
\end{tabular}

\subsection{Bio-Sand Filtration Performance}

\subsubsection{Turbidity Reduction}

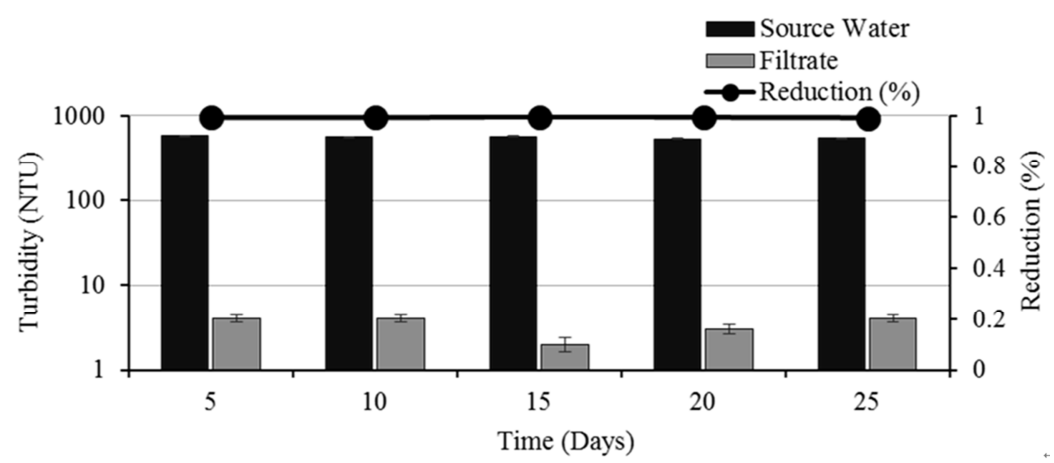

Figure 2. Turbidity reduction efficiency over the length of the BSF runs.

As shown in the Figure 2, a significant reduction of turbidity in the filtrate than source water and performance consistency can be noted. The average turbidity removal efficiency for the BSF is around $99.4 \%$ which was significantly higher than those documented for BSF in the past $[15,25-27]$. Turbidity removal trend showed a consistent expression over the length of the BSF runs. On the other hand, no significant changes were found in the out flow rate due to high turbidity in the feed water. This may be due to an experimentally set flow rate of $50 \mathrm{~mL} / \mathrm{min}$.

\subsubsection{Total Coliform and Fecal Coliform Reduction}

The maximum removal efficiency of total coliform for the filter was based on the assigning a value of $16 \mathrm{CFU} / 100 \mathrm{~mL}$ and presented a counting between $16-72 \mathrm{CFU} / 100 \mathrm{~mL}$ over the period of the BSF runs. And the average removal efficiency reached to 1.4-log by the BSF with at least 1.1-log reduction efficiency. Large fluctuations were seen between the feed total coliform and filtrate concentrations. The fecal coliform concentration was also observed to reduce by greater than $1.0-\log$ over the course of the tests where average removals were 1.3-log for BSF. And the maximum removal efficiencies for the filter was based on assigning a value of $8 \mathrm{CFU} / 100 \mathrm{~mL}$. There was a fair degree of consistency in the effluent quality suggesting that filter ripening had occurred prior to the commencement of testing to reach to its maximum performance.

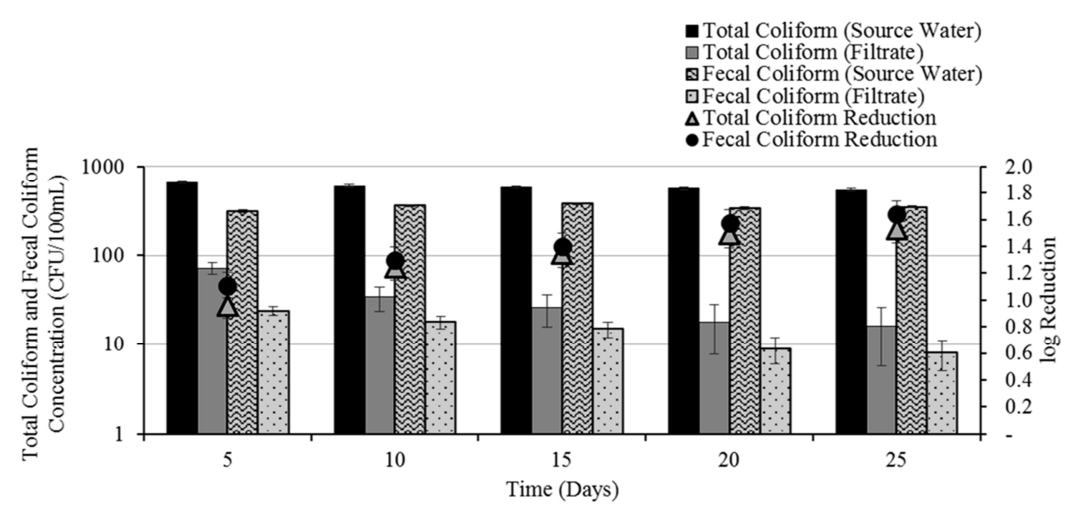

Figure 3. Total coliform and fecal coliform removal efficiency by the BSF over the period of the experiment. 
Biological activity in slow sand filter (SSF) is time dependent, as higher flow rates have shorter contact times between the source water and the microorganisms that break down the contaminants [28]. While previous studies have indicated that higher flow rates decrease bacterial straining by porous material [29]. Under the experimentally set operational flow rate of $50 \mathrm{~mL} / \mathrm{min}$ was thought as a lower flow rate to provide a higher contact time that could increase the filter's efficiency to remove contaminants. Overall, the consistently improved performance indicated the filter ripening occurrence. At the initial level, the lower bacterial removal performance can be thought due to lack of filter ripening. Baumgartner et al. [30] reported that total coliform removal by BSF decreased with an increase in charge volume. Similar observations were also made by Elliott et al. [31]. However, the filter accomplished $>97 \%$ microbial reduction on multiple days throughout the experiment. The reductions compare to the typical range of $93 \%$ to $99 \%$ that has been documented by previous researchers $[15,31-34]$. These results are consistent with what has been found in the literature for SSFs $[28,35]$. Overall, the BSF reduced a significant portion of microbial contamination in the filtrate that results in improved drinking water quality.

\subsubsection{Chlorination of Bio-Sand Filtrate}

Chlorine dosages of 2.4 and $4.8 \mathrm{mg} / \mathrm{L}$ were added to untreated pond water and Bio-Sand filtrate. Free chlorine residual was monitored over 24 hours. Bio-Sand filtration before chlorination were effective at maintaining free chlorine residual in stored water as shown in Figure 4. Initial doses were set $2.4 \mathrm{mg} / \mathrm{L}$ and $4.8 \mathrm{mg} / \mathrm{L}$ respectively. Analysis of the free chlorine residual results for 24 hours provided valuable insight into variation of chlorine demand in waters. At the initial dose of $2.4 \mathrm{mg} / \mathrm{L}$, the free chlorine residual level at 8 hours in treated water was found greater than $1.0 \mathrm{mg} / \mathrm{L}$ and at 24 hours the concentration was found $1.0 \mathrm{mg} / \mathrm{L}$ in the BSF filtrate. This free chlorine residual range was selected because it meets WHO and CDC SWS guidelines for free chlorine in drinking water $[36,37]$ and because less than $0.2 \mathrm{mg} / \mathrm{L}$ free chlorine may not adequately protect water from recontamination.

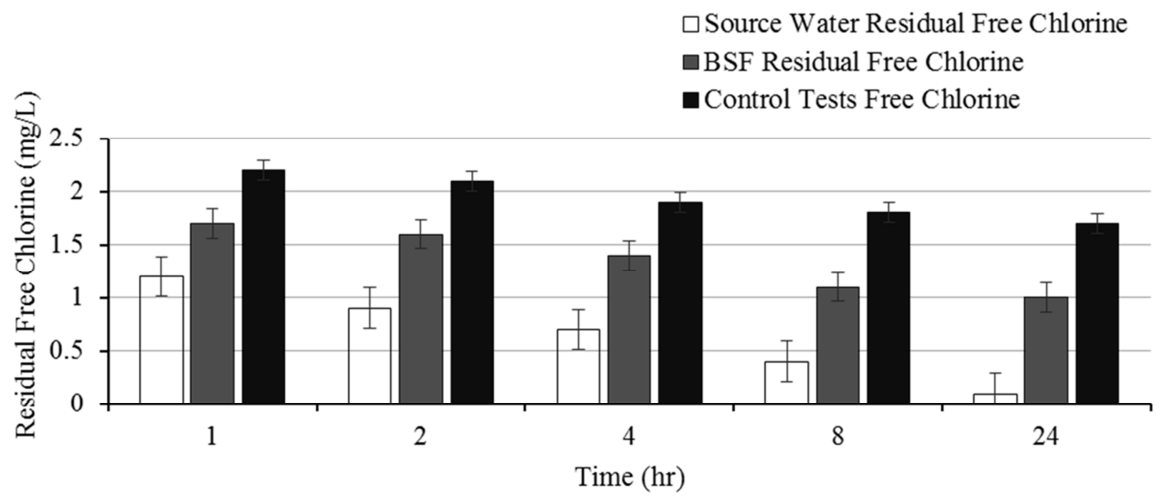

(a)

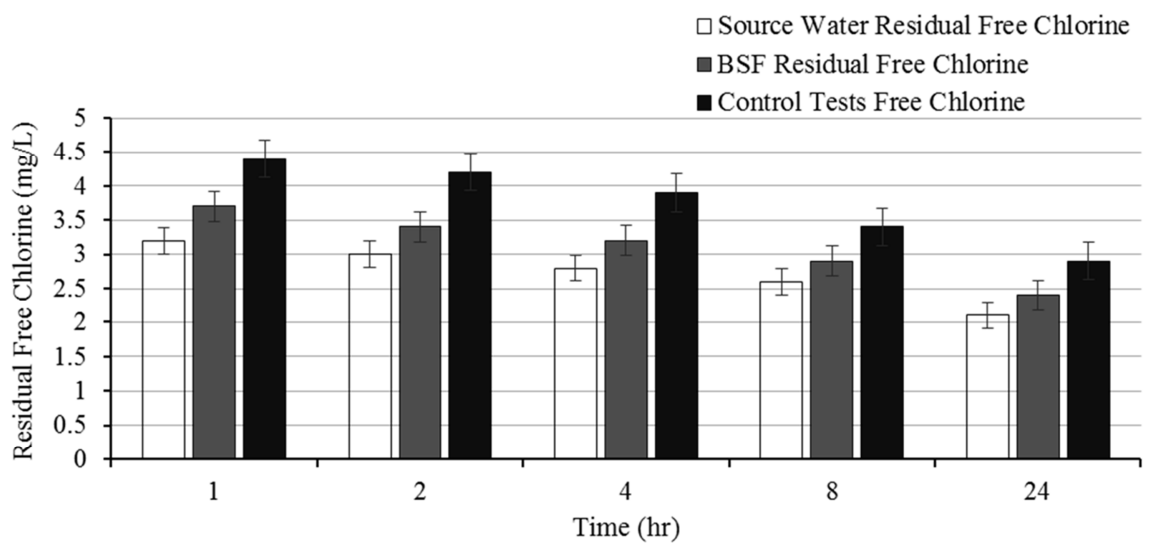

(b)

Figure 4. Efficacy of maintaining residual free chlorine concentration over 24 hours. The graphical representations are respectively- (a) At the dose of 2.4 mg/L; (b) At the dose $4.8 \mathrm{mg} / \mathrm{L}$.

On the other hand, the chlorine dose of $4.8 \mathrm{mg} / \mathrm{L}$ over 24 hours demonstrated a higher concentration that was greater than $2.0 \mathrm{mg} / \mathrm{L}$. The user taste acceptability concerns above 2.0 $\mathrm{mg} / \mathrm{L}$ free chlorine [38]. This residual concentration may not result into preferable level of the user taste over 24 hours. Maintaining free chlorine residual levels over time increases the effectiveness of the bleaching powder at inactivating any biological contaminants that may be introduced to the water 
during storage. The residual free chlorine of the $2.4 \mathrm{mg} / \mathrm{L}$ dose indicates and fulfills the recommendations by WHO [36]. In this case $2.4 \mathrm{mg} / \mathrm{L}$ dose is recommended for users in this study after filtration to protect the stored water. The chlorinated water is recommended for use after 24 hours from the time of chlorine addition. The use of sand filtration not only decreases turbidity, but also removes some of the compounds exerting chlorine demand and leads to maintenance of more consistent free chlorine residual levels over time.

\subsubsection{Potential Public Health Risk Reduction}

Health authorities generally accept that microbiologically safe water plays an important role in preventing outbreaks of waterborne diseases [39]. The filtration technique in this study provided a low-cost surface water (pond) treatment system with chlorination of the filtrate that resulted in the safe drinking water quality. Even though such a solution in this study seems to be so effective from an ecological point of view, potential health risks from ingestion of untreated pond water can be taken into account in the hard-to-reach coastal areas in Bangladesh. Moreover, there is evidence that chlorination and filtration of water supplies contributed to substantial health gains in the late $19^{\text {th }}$ and early 20th century [40]. However, much of the epidemiological evidence for increased health benefits following improvements in the quality of drinking water has been equivocal, particularly in low-income settings [41-43]. Besides, this household drinking water treatment system reduced the risks of contamination and recontamination between the sources and at the point of consumption.

\section{Conclusion}

This study investigated the applicability of a locally assembled low-cost Bio-Sand Filter for safe drinking water supply and to promote health in hazard-prone hard-to-reach coastal area of Bangladesh. The conventional drinking water sources (rivers and groundwater) in the coastal area have become contaminated recently due to saltwater intrusion from the rising sea levels and frequent natural disaster, and pond water is the only available source of drinking water. The filter removed turbidity (>99\%) and microbial contamination (1.5 to $1.6-\log$ reduction) significantly from pond water. Though the BSF could reduce a significant amount of microbial contamination in the effluent, it does not meet the microbiological standards by WHO of Total Coliform and Fecal Coliform (less than 1CFU per 100ml). Post-chlorination of the filtrate analysis result meets up the WHO recommendations of having the residual free chlorine level over 24 hours to protect stored water from recontamination. The filter reduces the risks of contamination between the water source and the home, by providing drinking water through treatment at the household level. Overall the Bio-Sand filter is, and will continue to be a simple, effective, low-cost household level water treatment device for drinking water supply in the hazard-prone hard-to-reach coastal areas in Bangladesh.

\section{References}

[1] United Nations Committee on Economic, Social and Cultural Rights (CESCR), "International Covenant on Economic, Social and Cultural Rights", 2003. http://www.unhcr.org/refworld/docid/4538838d11.html, accessed February 13, 2016.

[2] WHO, Guidelines for Drinking-Water Quality: Recommendations, vol. 1 of Incorporating First and Second Addendum, 2008. World Health Organization, Geneva, Switzerland, 3rd edition.

[3] United Nations Development Programme (UNDP), 2006. "UNDP Human Development Report, Beyond Scarcity: Power, poverty and the global water crisis". http://hdr.undp.org/en/reports/global/hdr2006/, accessed February 10, 2016.

[4] WHO, 2008. "An interview with Mahmudur Rahman: Bangladesh arsenic agony. Bulletin of the WHO”, vol. 86, no. 1 , pp. 11-12.

[5] WHO/UNICEF, 2015. Joint Monitoring Programme for Water Supply and Sanitation (JMP), "Progress on Drinking Water and Sanitation", MDG Assessment report.

[6] Dankelman I., K. Alam, W. B. Ahmed, Y. D. Gueye, N. Fatema, and R. M. Kutin, 2008. "Gender, climate change and human security: Lessons from Bangladesh, Ghana and Senegal." Report prepared for Hellenic Foundation for European and Foreign Policy (ELIAMEP) by the Women's Environment and Development Organization (WEDO), ABANTU for Development in Ghana, Action Aid Bangladesh, and ENDA in Senegal.

[7] Quazi A. R., 2006. "In search of safe drinking water: In the context of climate change and salinity. Satkhira, Bangladesh: Uttaran and Water Committee".

[8] Ministry of Environment and Forest (MOEF), 2006. "Impact of Sea-Level Rise on Land Use Suitability and Adaptation Options: Coastal Land Zoning in the Southwest Dhaka, Bangladesh", Ministry of Environment and Forest.

[9] Hoque R. M., 2009. "Access to safe drinking water in rural Bangladesh: Water governance by DPHE". Master's Thesis, Institute of Governance Studies, BRAC University, Dhaka, Bangladesh.

[10] Islam M. A., H. Sakakibara, M. R. Karim and M. Sekine, 2013. "Potable water scarcity: options and issues in the coastal areas of Bangladesh", Journal of Water and Health, vol. 11, no. 3, pp. $532-542$.

[11] Wash Cluster, WaterAid and Unicef, 2009. "Learning and Knowledge Sharing Workshop on Response to Cyclone Aila, Khulna, Bangladesh". From

$<$ http://cccm.iom.org.bd/file/pdf/29.pdf $>$, accessed February $10,2016$.

[12] Khan A., S. K. Mojumder, S. Kovats and P. Vineis, 2008. "Saline contamination of drinking water in Bangladesh", Lancet, pp. 371-385.

[13] Fewtrell L., and J. M. Colford, 2004. "Water, Sanitation and Hygiene: Interventions and Diarrhoea. A Health, Nutrition and Population Discussion Paper", World Bank Human Development Network. Washington DC. 
[14] Barnes D., C. Collin, and S. Ziff, 2009. "The Bio-Sand Filter, Siphon Filter, and Rainwater Harvesting", Report, Massachusetts Institute of Technology, Cambridge, MA.

[15] Duke W. F., R. N. Nordin, D. Baker, and A. Mazumder, 2006. "The use and performance of Bio-Sand filters in the Artibonite Valley of Haiti: a filed study of 107 households", journal of Rural and Remote Health, vol. 6 no. 3, pp. 570.

[16] Sobsey M. D., C. E. Stauber, L. M. Casanova, J. M. Brown, and M. A. Elliott, 2008. "Point of Use Household Drinking Water Filtration: A Practical, Effective Solution for Providing Sustained Access to Safe Drinking Water in the Developing World", Environmental Science Technology, vol. 42, no. 12, pp. 4261-4267.

[17] UNICEF/WHO, 2009. Diarrhea: Why children are still dying and what can be done. The United Nations Children"s Fund and World Health Organization.

[18] Clasen T. F., 2008. "World Health Organization Guidelines for Drinking-water Quality Scaling up Household Water Treatment Looking Back, Seeing Forward”, WHO, Geneva, Switzerland.

[19] WHO, "Calcium Hypochlorite. Fact Sheet 2.19", 2006. http://www.who.int/water_sanitation_health/hygiene/emergen cies/fs2_19.pdf, accessed April 13, 2014.

[20] CAWST, "Bio-Sand Filtration Construction Manual", Center for Affordable Water and Sanitation Technology, Calgary, Canada, 2012. Available from: http: //www.cawst.org/en/resources/Bio-Sand filter, accessed February 12, 2016.

[21] HACH Company, "DR/2100 Spectrophotometer Procedure Manual", Loveland, Colorado".

[22] Standard Methods for the Examination of Water and Wastewater, 21st edition, 2006. American Public Health Association/American Water Works Association/Water Environment Federation, Washington DC.

[23] HACH Company, "DR/2700 Spectrophotometer Procedure Manual", Loveland, Colorado".

[24] Ahmed F., 1996. "Coastal water supply in Bangladesh", "Reaching the Unreached: Challenges For The 21st Century", 22nd WEDC Conference, New Delhi, India.

[25] Lee T-L., 2001. "Bio-Sand Household Water Filter Project in Nepal", Massachusetts Institute of Technology Master of Engineering Thesis, Cambridge, MA, USA.

[26] Buzunis B. J., 1995. "Intermittently Operated Slow Sand Filtration: A New Water Treatment Process". Master's Thesis, University of Calgary, Canada.

[27] Kikkawa I., 2008. "Modification of the Bio-Sand Filter in the Northern Region of Ghana", Massachusetts Institute of Technology Master of Engineering Thesis, Cambridge, MA, USA.

[28] Huisman L., and W. E. Wood, "Slow Sand Filtration", 1974. World Health Organization, Geneva, Switzerland.

[29] Stevik T., A. Kari, G. Ausland, and J. Fredrik Hanssen, 2004. "Retention and removal of pathogenic bacteria in wastewater percolating through porous media: a review", Water Research, vol. 38 , pp. 1355-1367.
[30] Baumgartner J., S. Murcott, and M. Ezzati, 2007. "Reconsidering 'appropriate technology': the effects of operating conditions on the bacterial removal performance of two household drinking-water filter systems", Environmental Research Letters, vol. 2, pp. 1-6.

[31] Elliott M. A., C. E. Stauber, F. Koksal, F. A. DiGiano, and M. D. Sobsey, 2008. "Reductions of E. coli, echovirus type 12 and bacteriophages in an intermittently operated household-scale slow sand filter", Water Research, vol. 42, pp. 2662-2670.

[32] Baig S. A., Q. Mahmood, B. Nawab, M. N. Shafqat, and A. Pervez, 2011. "Improvement of drinking water quality by using plant biomass through household Bio-Sand filter-a decentralized approach", Ecological Engineering, vol. 37, pp. $1842-1848$

[33] Stauber, C., Elliott, M., Koksal, F., Ortiz, G., DiGiano, F. \& Sobsey, M., 2006. 'Characterisation of the Bio-Sand filter for E. coli reductions from household drinking water under controlled laboratory and field use conditions', Water Science and Technology, 54 (3), 1-7.

[34] Vanderzwaag, J., Atwater, J., Bartlett, K., \& Baker, D., 2009. Field evaluation of long-term performance and use of Bio-Sand filters in Posoltega, Nicaragua. Water Quality Research Journal of Canada, 44, 111-121.

[35] Muhammad, N., Ellis, K., Parr, J. \& Smith, M., 1996. 'Optimization of slow sand filtration', Reaching the Unreached, Challenges for the 21st Century. 22nd WEDC Conferences, 283-285.

[36] WHO, "Chlorination Concepts. Fact Sheet 2.17", 2006. $\mathrm{http}: / / w w w . w h o . i n t / w a t e r$ sanitation health/hygiene/emergen cies/fs2_19.pdf, accessed February 13, 2016.

[37] Centers for Disease Control and Prevention (CDC), "Safe Water Systems", http://www.cdc.gov/safewater/publications_pages/chlorineresi dual.pdf, accessed March 14, 2016.

[38] Lantagne D. S., 2008. "Sodium hypochlorite dosage for household and emergency water treatment", Journal of American Water Works Association, vol. 100, no. 8, pp. 106-119.

[39] Reynolds K. A., K. D. Mena, C. P. Gerba, 2008. "Risk of waterborne illness via drinking water in the United States", In: Whitacre DM editor(s), Reviews of Environmental Contamination and Toxicology, vol. 192, pp. 117-58, New York: Springer.

[40] Cutler D., G. Miller, 2005. "The role of public health improvements in health advances: the twentieth-century United States [2005]", Demography, vol. 42, no. 1, pp. 1-22.

[41] Clasen T., I. G. Roberts, T. Rabie, W. P. Schmidt, S. Cairncross, 2006. "Interventions to improve water quality for preventing diarrhea", Cochrane Database of Systematic Reviews, Issue 3 [DOI: 10.1002/14651858.CD004794.pub2].

[42] Waddington H., B. Snilstveit, H. White, L. Fewtrell, 2009. "Water, sanitation and hygiene interventions to combat childhood diarrhoea in developing countries". http:// www.3ieimpact.org/evidence/systematic-reviews/details/23/. (Accessed 15 March, 2016).

[43] Cairncross S., C. Hunt, S. Boisson, K. Bostoen, V. Curtis, I. C. H. Fung, 2010. "Water, sanitation and hygiene for the prevention of diarrhea", International Journal of Epidemiology, vol. 39, pp. 193-205. 